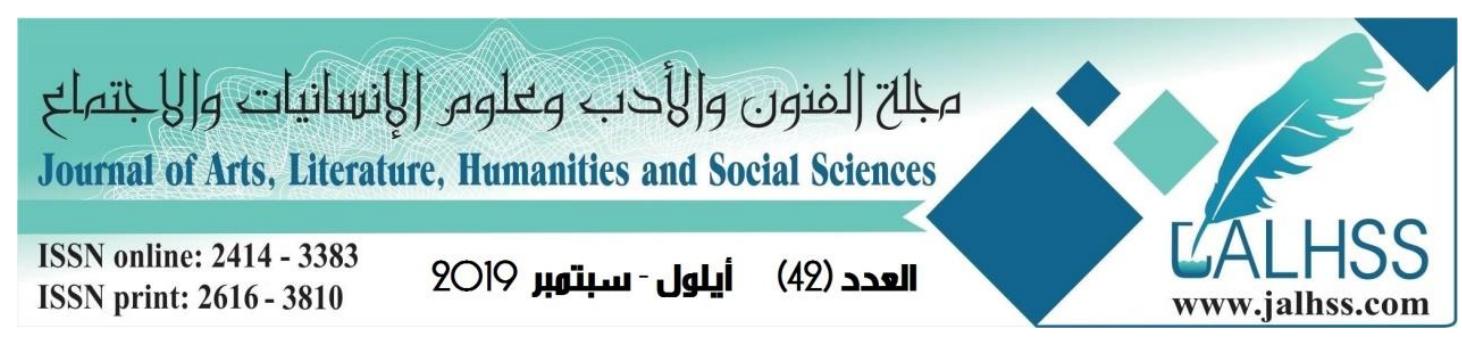

\title{
The Translation of Ambiguous Structures from English into Arabic
}

\author{
Lecturer \\ Osama Misbah Mahmood Al-Hamdani \\ Department of Translation \\ College of Arts - Mosul University \\ Iraq
}

\author{
Assist. Lecturer \\ Sanabil Azhar Sulaiman Al-Hamdani \\ Department of Translation \\ College of Arts - Mosul University \\ Iraq
}

\begin{abstract}
No doubt, ambiguity in language is due to meaning. It is any stretch of language, to use pragmatic term that can have more than one meaning. This multiplicity of meaning may be due to several factors. Such as semantic, pragmatic, phonetic, phonological, stylistic, cultural, syntactic, structural, grammatical ( among many other factors). In general, ambiguity means that any phoneme, morpheme, word, phrase, expression or any statement which can have more than one meaning or more than one interpretation. The intended meaning of the ambiguous expression can be determined by context of situation (context) and linguistic context (cotext). The problem in this study is that the ambiguous expression can be translated into the target language, but not as an ambiguous expression. This means that the translator will run into the problem of untranslatability in that, he will give translations in which each one will carry one meaning and not different meanings of the structure in question. As a result, he will be unable to give an effective rendering which can be considered as an ambiguous counterpart to that of the source language ( English Language). Hence, comes this study. So, the main aim of this study is to translate such ambiguous structures from English to ambiguous expressions in Arabic. To achieve the aim of this study, it is hypothesized that the ambiguous structures can be translated by giving all the interpretations they carry, but not into ambiguous structures that can be considered as counterparts of the source language texts. To test the validity of the above hypotheses, the data in question were given to six B.A fourth year students in the department of translation/ College of Arts / Mosul University. As for methods of translation, this study adopts Newmark's (1988) semantic and communicative translations. The main findings the study arrived at are (1) the subjects succeeded in translating the texts under question and gave the different interpretations; yet, sometimes they failed to give their counterparts which can be considered as effective ambiguous structures.
\end{abstract}




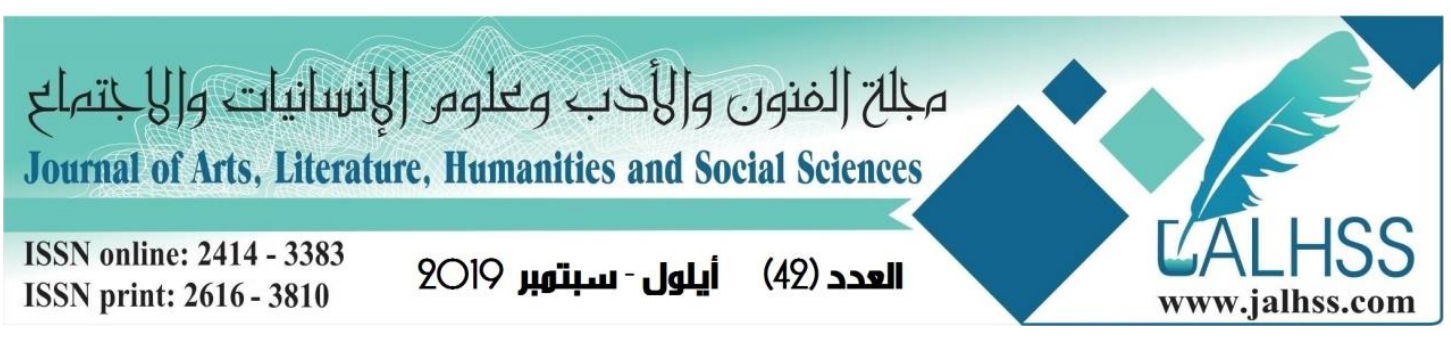

\section{Statement of the Problem}

Ambiguity has always been a serious problem for translators challenging their ability and competence. To overcome this problem, translators must fully understand and perceive the accurate sense and the communicative meaning of ambiguity. Regarding the six Arabic translations of the data under discussion, one can clearly realize the inconsistency and divergency in tackling ambiguity by the six subjects ( fourth year students in the department of translation/ College of Arts / Mosul University / Iraq). Consequently, they differ in reproducing the similar effect of the ambiguous structures to the target language readers to that experienced by the source language readers. Added to this, the six subjects suffer from deleting the ambiguity, and adding irrelevant words which in turn weakens the power and effect of the ambiguity, spoils its aesthetic aim and distorts its ambiguous structure. This paper; therefore, is an attempt to solve these problems by proposing suitable solutions.

\section{Aims of the Study}

It is to be emphasized from the very beginning that this study does not aim to criticize or just show the defects of the six subjects, though it shows the drawbacks of some of them. Rather, it aims at :

1. Studying ambiguous structures in terms of their grammatical structures and their meanings as well as the intended meanings of the writers of the data under study.

2. Using Newmark's types of translation, namely semantic translation and communicative translation.

3. Showing the need to adopt an interdisciplinary approach in order to arrive at a better account of the process of translating ambiguous structures.

4. Revealing that the concept of 'adequacy' is more useful than the concept of 'equivalence', particularly, when the discussion is concerned with the adequacy of a target structure to meet the needs of its receivers and serve its intended aims.

\section{Hypotheses}

It is hypothesized in the present paper that: 


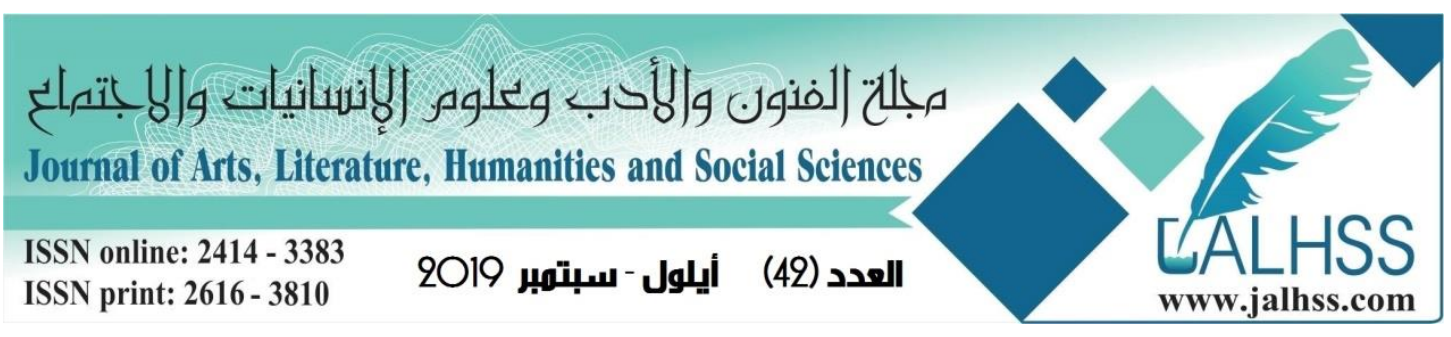

1. There is no unanimous agreement among the six subjects of ambiguous structures in conveying the same effect to the target language reader as that used by the source language reader.

2. Transferring the ambiguous structures of the source language to target language is the appropriate procedure for translating ambiguity in the data in question.

\section{Procedures and Data Collection}

The procedure used in the current paper is as follows:

1. A theoretical background of ambiguity was given.

2. Twelve different ambiguous structures were selected from books of grammar, semantics, pragmatics and stylistics as data for the study in question.

3. The selected ambiguous structures under investigation were given to six subjects (fourth year students in the department of translation/ college of arts/ Mosul university ), to be translated from English into Arabic.

4. A thorough discussion, comments and comparison of the source language texts and target language texts were given.

5. Findings of the data analysis were analyzed and discussed in terms of comprehensive tables.

6. Some conclusions were drawn in the light of the findings of the data analysis.

\section{Introduction}

The study of ambiguity is considered one of the most important topics in semantics, stylistics, pragmatics, syntax, politics and literature that is worthy to be investigated. Ambiguity can be amusing, but it can also be misleading. Politicians, for instance, deliberately use ambiguous expressions, utterances and structures in order to be understood indirectly and sometimes in different ways by different people. Generally speaking, ambiguity can be defined as a phoneme, morpheme, word, phrase, or structure which can have more than one meaning. The ambiguous structure can have at the same time two meanings or even multiple meanings, sometimes, more than ten meanings. For this reason, ambiguous structures or expressions result in vagueness and confusion. They shape the basis for instances of unintended humor (see Bhabha, 1994: 45, Poesio and Artstein, for all what we have said, 2005:1). 


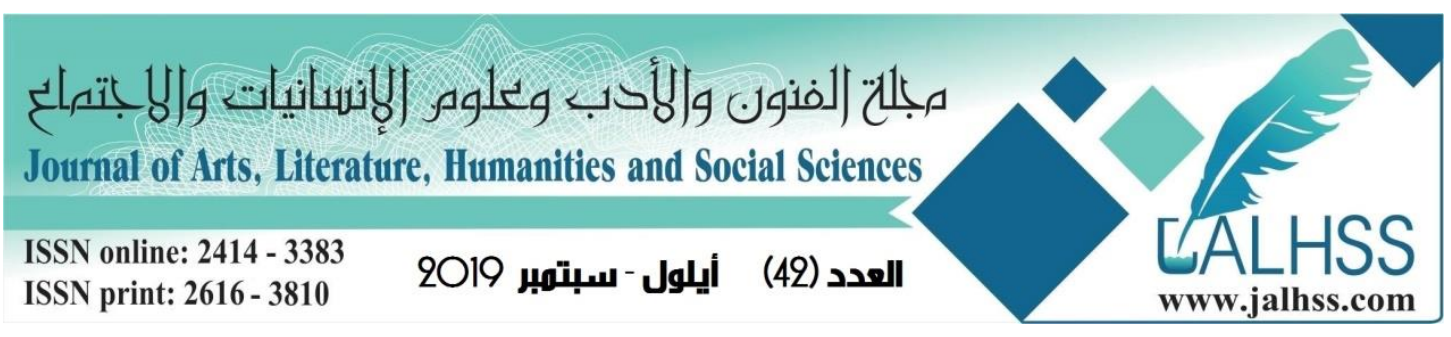

Hurfard et al (2007:128) state that a structure or any other expression is ambiguous if and only if it has more than two or more paraphrases which are not themselves paraphrases of each other. Let us have the following examples on the level of word:

1. "Heavy" can be a heavy smoker.

2. "Heavy: can be a heavy meal.

3. "Heavy" can be a heavy table to be lifted.

4. "Heavy" can be heavy rain.

The following examples are also interesting:

1. "Credit" can be an ability to acquire something prior to expected payment .

2. "Credit" can be an acknowledgement of positive contribution.

Ambiguity also can be defined as a situation in which something can be understood in more than one way and it is not clear which meaning is intended by the speaker or writer unless it is contextualized or co-textualized. Ambiguous structures can occur when the grammatical arrangement of words makes the meaning of a certain utterance unclear. The meaning of each word may be clear ,but the overall meaning cannot be understood. Let us consider the following examples:

1. “Save soap and waste paper”( a World War II Slogan ).

2." I saw the man in the bank"

In example (2) the sentence is ambiguous if one has to decide who was in the bank (for the last two examples, see Baker,2006: 50, Bates, 2007:65). Al-Sulaimaan (2016: 2) defines " ambiguity as a linguistic phenomenon which refers to a word, a phrase, a sentence or any linguistic expression that has more than one meaning or interpretation . It can be of different types such as phonetic, phonological, morphological, structural, syntactic, grammatical, stylistic, cultural ( among many others). Any linguistic expression with more than one interpretation is said to be multiply ambiguous as in the "run" which has more than sixty meanings. (Neubert \& Shreve, 1992).

To conclude, one can say that ambiguity is a linguistic phenomenon in which a linguistic expression can have more than one meaning or interpretation, in which one of them is clear and the others are implied 


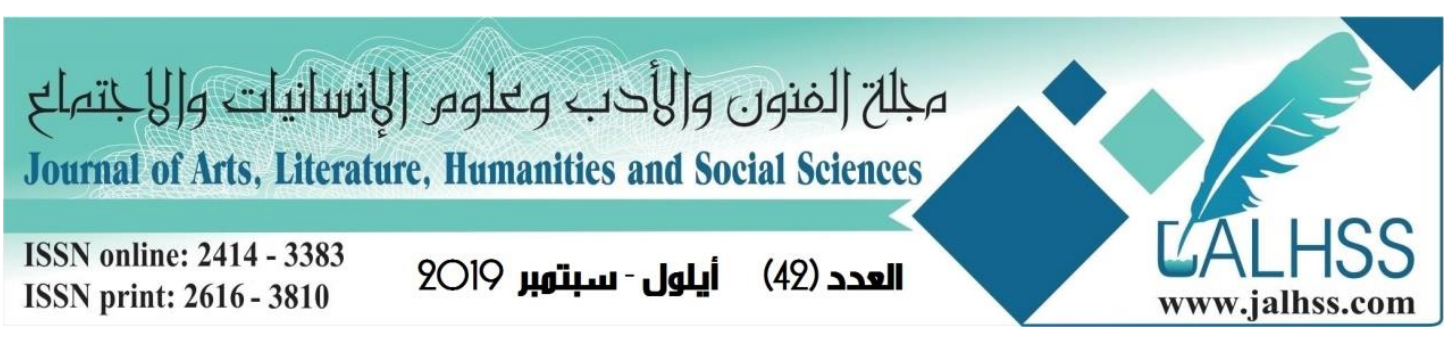

\section{Types of Ambiguity}

Semanticists and pragmatists believe that languages are notoriously ambiguous on different levels such as phonemes, morphemes, words, phrases, utterances and sentences or any stretch of language that has more than two interpretations. Ambiguity can be deduced simultaneously or deliberately. No doubt, scholars of semantics, stylistics, pragmatics, Literature, phonology, morphology, syntax, language of diplomacy and politics have tackled this phenomenon differently. Some of them viewed it as an utterance with more than one meaning. Some others compared it with paraphrasing. Still others have considered it as a defect or a partial failure of communication (Jeenan, 1975: 20). For these reasons we find that ambiguity is of different types such as phonological or phonetic, morphological, lexical, syntactic, structural, semantic, pragmatic, stylistic, political (among many other types). In fact, ambiguity has a great role in the process of understanding and comprehending. Our study considers the " issue of "structures " because this word is relative and includes all types of ambiguity, simply because all units or stretches of any language have structures. Hence, our study is entitled "The Translation of Ambiguous Structures from English into Arabic ). This means that structure does not mean only syntactic ambiguity and grammatical ambiguity because all other units of language have got structures. When all types come together, no doubt, semantic and pragmatic ambiguity will arise. In what follows, the main types will be presented.

\subsection{Semantic Ambiguity}

No doubt, real semantic ambiguity takes place not only on the lexical level, but also it occurs on the syntactic level where it results in two different syntactic structures depending on the interpretation (Muhonen and Purtonen, 2012: 2). This leads us to say that semantic ambiguity is the case that cannot be easily understood since it can be read in more than one way. Consequently, it can be said that the reason behind semantic ambiguity is scope, coordination, and referential ambiguity. Trosborg (1994: 9) and Poesio (2014:90) states that semantic ambiguity arises when a lexeme or a concept has an inherently diffused meaning based on widespread or informal usage. From this brief review, it is to confirmed that semantic ambiguity is the output of both lexical and syntactic ambiguities, simply, because the meaning is based on syntactic structure as well as the lexicons of that structure. Newman (2009:1268) believe that semantic ambiguity often occurs within a language. For instance, the word "organ" in English means a body part and a musical instrument. It can also cross a language boundary, such a given word form is shared in two languages ,but its 


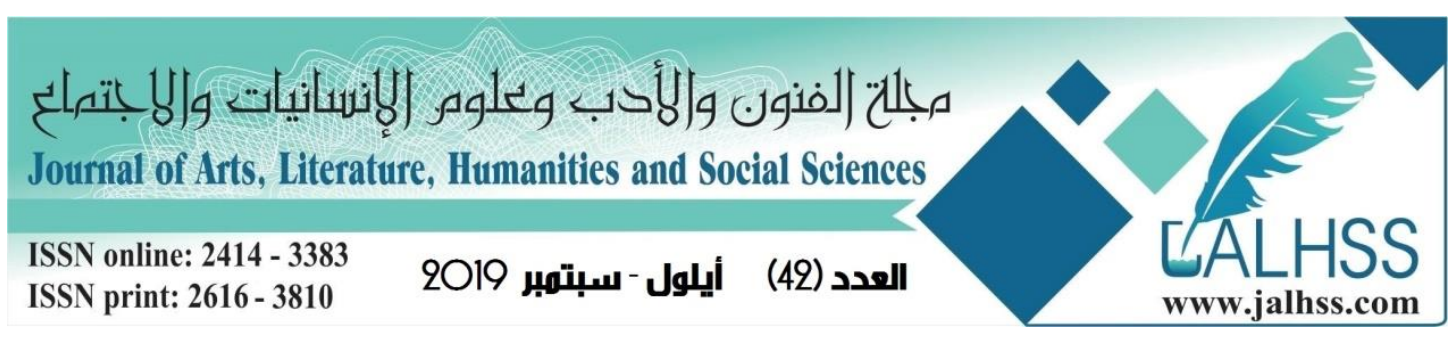

meanings are different ( e.g., the word "angel" means "sting " in Dutch). Consequently, bilingual individuals are; therefore, faced not only with ambiguity in each of their languages, but also with ambiguity across Languages.

\subsection{Pragmatic Ambiguity}

Pragmatic has been defined as the scientific study of Language in use. This means that this discipline is context bound to be understood. Its basic unit is the utterance which is a physical event or a concrete actual thing in the reality ( Alsulaimaan,2016 : 18). The meaning of an utterance is based on three elements which are lexicons, syntactic structure and context of situation. This differs from the semantic meaning which is the output of the lexicons and syntactic structure. The absence of one element results in ambiguity. Berry, et al (2003:12) states that pragmatic ambiguity occurs when an utterance has several meanings due to different contexts. The context involves co-text ( linguistic context). In other words the utterances uttered before and after the utter ance in question. Added to that the context of situation which is beyond language, in other words, whatever surrounds the speech event. This kind of ambiguity is the output of the deictic ambiguity. Examples:

1. Give a man a fish, and he will live one day.

Whereas:

2. Give a man a net, and he will live for ever.

So the net is much more pragmatic direct than few days (Larson, 1984: 20, and Muhonen and Purtonen, 2012:3)

\subsection{Cultural Ambiguity}

Culture can be defined as life itself which involves everything in the life of a certain community or nation, just like practicing religion, customs, habits, type of fashions used, celebrating certain ceremonies, among many other things in the life of communities and nations. No doubt, culture and language are closely interrelated since language reflects culture. Hence, comes the statement which says " one cannot digest or even master a little bit the language of a certain nation unless he/ she knows the culture of that language or target language. For this reason, theorists of translation claim that a would-be translator must be bicultural before being bi-lingual (Bassnett 


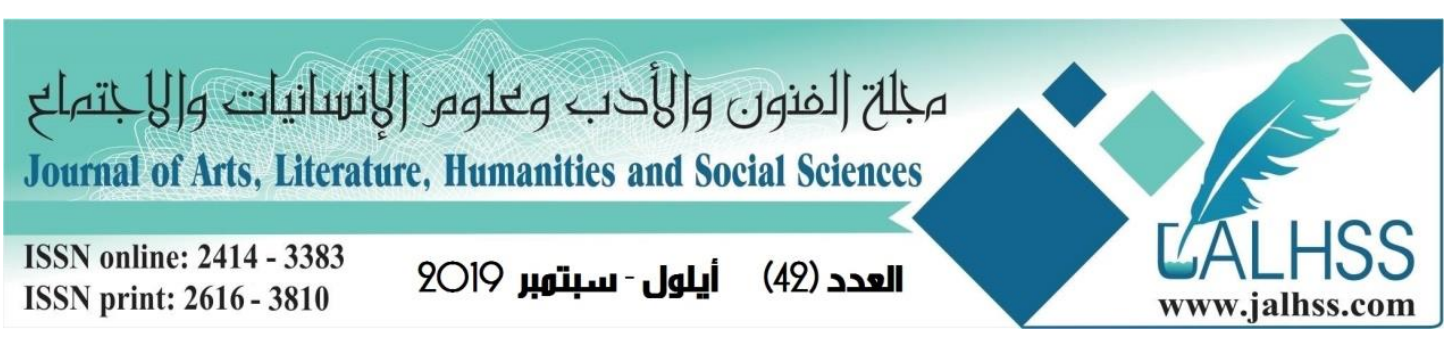

and Lefevere, 1990:40, Bassnett, 1991: 30). Consequently, if the translator knows his own culture, he will be able to understand the cultural ambiguity and ; therefore, he will be able to transfer this ambiguity to the target language. Let us have this religious ambiguity as an example "Jesus" in English and "Easa" in Arabic have the same referent; yet, they have different connotations in each culture. "Jesus," in English is considered as the son of GOD, whereas " Easa " in Islamic culture is believed to be the prophet of GOD (Al-Sulaimaan, 2016:3). Such type of ambiguity is really, problematic. Another cultural example is interesting. A husband and wife can divorce each other in "Islamic culture" whereas in "Christianity" they can be separated, simply, since there is no divorce in "Christianity".

To sum up one can say that there are no absolute identical cultures which have the same values, traditions, history, systems, social norms, customs, habits, beliefs, among many other things. This leads us to say that translators must beware of such differences between source and target cultures, and avoid such clashes between cultures.

\subsection{Structural Ambiguity}

Structural ambiguity has been defined as a situation in which a sentence or an utterance or any linguistic structure can be interpreted in more than one way due to the linguistic unit structure whether phoneme, morpheme, lexeme, phrase, sentence or any grammatical structure. Structural ambiguity also can be defined as the presence of two or more possible meanings within a single sentence, utterance, phrase, or any linguistic unit. The intended meaning of a structurally ambiguous is unit if language can, often but not always be determined by context and cotext. Structural ambiguity means how the organization of lexicons can pose problems for interpretation by humans and software systems (Gunn, 1999:20). This term is often contacted with lexical ambiguity, which often arises because words or lexemes can be characterized by multiplicity of meaning. These two types of ambiguity are good examples of linguistic ambiguity, which also results from other things including figurative language and vagueness. The following examples are interesting:

1. Competent lawyers and judges.

This example reveals that the lawyers are competent. However, it may also mean that both lawyers and judges are competent.

2. They are milking sheep. 


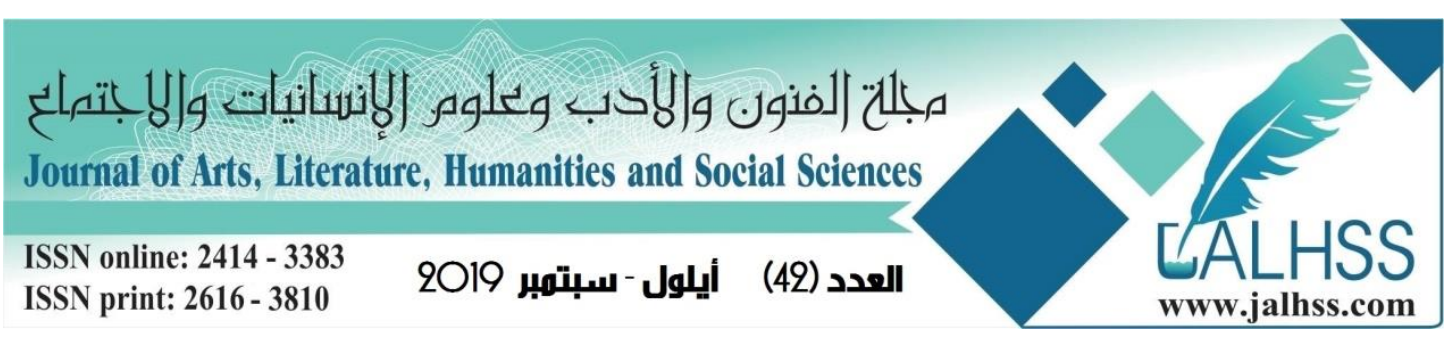

This example is structurally ambiguous. Its ambiguity is due to the subject "they" which may mean that some workers are milking sheep or it may mean that sheep are of the kind that give much milk (Conway, 2002:20).

To conclude, such kind of ambiguity is due to the structure of the linguistic unit which results from foregrounding, backgrounding, organization of the elements of the structure or even markedness theory. It also may be due to the Supra-segmental features of language such as stress, rhythm, intonation, pause or juncture.

\section{Translation and Methodology}

Generally, translation means replacing the source text with the target text taking as much as possible all the elements such as lexical, syntactic, semantic, pragmatic, stylistic, literary, textual, discoursal and cultural of both languages into consideration. The term translation is very comprehensive. It can be defined in terms of finding equivalence, transference of meaning, product, process, extent, rank, level. It also can be viewed differently in an accordance with its different types such as literary, non literary, word for word, literal, formal, dynamic, interlingual, intra-lingual, interlingual, inter-semiotic, free, adaptation, semantic, and communicative among many others (Catford,1965, Nida,1975, Savory, 1968, Jakobson, 1967 , Newmark, 1988). In our study, we will focus on Newmark's types of translation which are semantic and communicative, simply, because both are the gist and output of those who preceded him. Added to this, they are very comprehensive and can be viewed either in terms of transference of meaning, when a translator run into the problem of untranslatability and cannot find equivalence or it can be viewed in terms of finding equivalence. Hence, comes the problem of our study in that ambiguous structures can be translated according to their different meanings; yet, they cannot be translated into ambiguous structures effectively. The reason behind that is both English and Arabic are genetically different languages.

\section{Newmark's Methods of Translation}

No doubt, semantic translation focuses on lexicons and syntactic structure of the texts in question, I.e. it is after finding equivalence. However, communicative translation concentrates on lexicons, syntactic structures in relation to context whether linguistic context (co-text) or context of situation. This means that communicative 


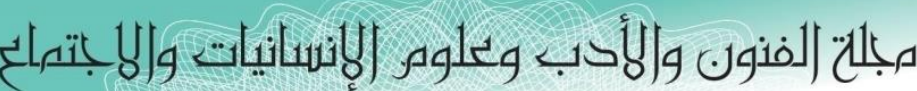

Journal of Arts, Literature, Humanities and Social Sciences

ISSN online: 2414 - 3383

ISSN print: 2616 - 3810

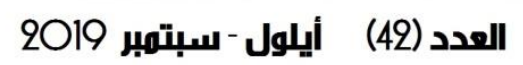

translation seeks translation in terms of transference of meaning. In what follows, both types will be explained in some details.

\subsection{Semantic vs. Communicative Translation}

The concepts of semantic and communicative translation represent Newmark's contribution to general translation theory (1988a, 1988b \& 1991) .

1. In communicative as in semantic translation, provided that equivalent effect is secured, the literal word for word translation is not only the best, it is the only valid method of translation. There is no excuse for unnecessary "synonyms" or elegant variations. Let alone paraphrases, in any type of translation.

2. Both semantic and communicative translation comply with the usually accepted syntactic equivalents or correspondences for the two languages under investigation.

3. Communicative and semantic translation may well coincide. In particular, where the text conveys a general rather than a culturally bound message and where the matter is as important as the manner.

4. There is no one communicative or one semantic method of translating a text. These are in fact widely overlapping bands of methods. A translation can be more, or less, semantic more or less communicative, even a particular section or sentence can be treated more communicatively or less semantically.

5. The vast majority of texts require communicative rather than semantic translation.

6. A communicative translation may well be a useful introduction, a simplified version, to the semantic translation of such texts.

7. There is no reason why a basically semantic translation should not also be strongly communicative.

8. Meaning is complicated, many -leveled A network of relations, as devious as the channels of thought in the brain. The more communication, the more generalization, the more simplification, the less meaning.

\section{Data Analysis and Discussion}

The ground has now been furnished for a full-dress analysis and discussion of ambiguous structures which can be semantic, pragmatic, syntactic, and cultural 


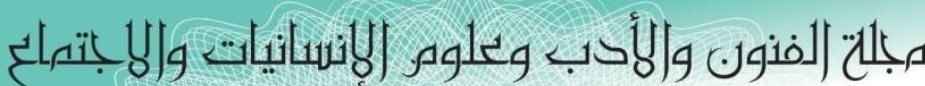

Journal of Arts, Literature, Humanities and Social Sciences

ISSN online: 2414 - 3383

ISSN print: 2616 - 3810

\section{العدد (42) أيلول - سبتمبر 2019}

structures, as we have already proved that every type of ambiguity has structure. The data to be prepared will be analyzed by making use of our literature review and the translation methods that have been reviewed and selected as a model for recommending the most appropriate transference of the structures in question.

\section{Source Language Text}

(SLT) (1):

They are milking cows.

(Shane,2000: 7).

Interpretation(1): Cows are giving milk, i.e., milky cows.

Interpretation(2): Some people are milking cows.

\section{Target Language Texts (TLTs)}

\begin{tabular}{|c|c|}
\hline انهم يحلبون البقرات & \\
\hline انهم يحلبون البقرات & \\
\hline انها بقرات حلوبة. & \\
\hline البقر ات حلوبة. & \\
\hline انها بقرات حلوبة. & \\
\hline أنهن يحلبن البقرات. & \\
\hline
\end{tabular}

Text Analysis(1):

\begin{tabular}{|c|c|c|c|}
\hline \multirow{2}{*}{ Subject } & \multicolumn{2}{|c|}{ Translation } & Interpretation \\
\cline { 2 - 4 } & Semantic & Communicative & 2 \\
\hline 1 & + & & 2 \\
\hline 2 & + & + & 1 \\
\hline 3 & & + & 1 \\
\hline 4 & & + & 1 \\
\hline 5 & + & & 2 \\
\hline 6 & & & 2 \\
\hline
\end{tabular}




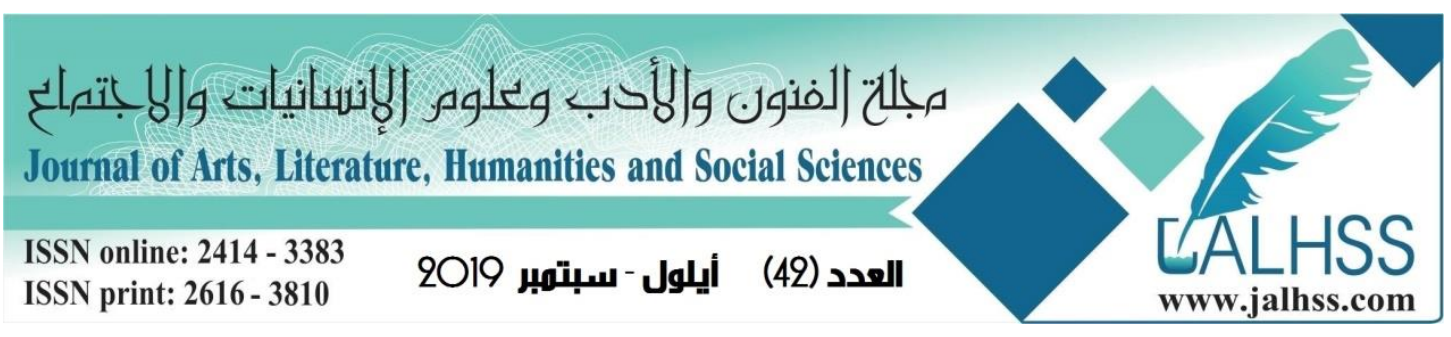

\section{Discussion}

A close inspection of the above translations, reveal that subjects 1, 2, and 6 have used semantic translations. As for interpretation, they succeeded in conveying just the second interpretation. Regarding subjects 3, 4, 5, it seems that they used communicative translation because they used nominal sentences, whereas the source language text is verbal. As for meaning, they succeeded in transferring the first interpretation. What is striking now, is that both groups could not translate the ambiguous structure in question into Arabic as an ambiguous structure. Consequently, the ambiguous structure under discussion can be translated communicatively to have both senses as follows:

$$
\text { انهم يحلبون البقر ات الحلوبة. }
$$

Another interpretation, If and only if, we take presupposition into consideration, we can say that the first group succeeded in conveying the ambiguous structure into Arabic as an ambiguous structure, simply, because milking cows presupposes that cows are milky and give milk, otherwise how these people are milking cows.

\section{SLT(2):}

Twenty six soldiers entered the camp. $\quad$ (Conway,2002:10)

Interpretation (1): The number of the soldiers that entered the camp is twenty six.

Interpretation (2) : the number of the soldiers that entered the camp is twenty, but all are sick phonologically speaking.

\section{TLTs}

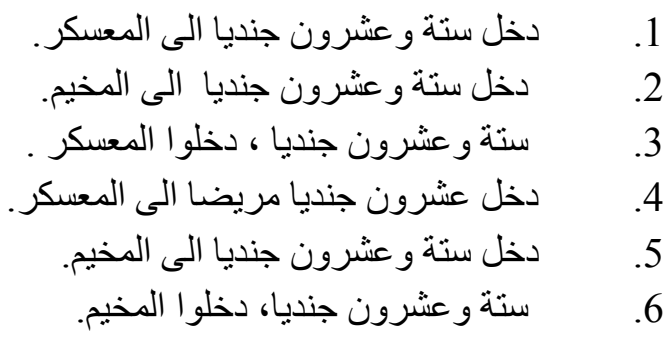




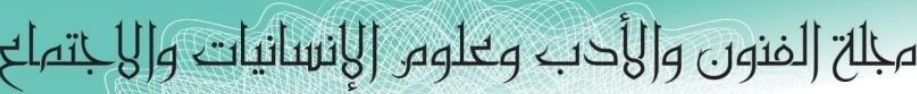

Journal of Arts, Literature, Humanities and Social Sciences

ISSN online: 2414 - 3383

ISSN print: 2616 - 3810

العدد (42) ايلول -سبتمبر 2019

Text Analysis (2):

\begin{tabular}{|c|c|c|c|}
\hline \multirow{2}{*}{ Subject } & \multicolumn{2}{|c|}{ Translation } & \multirow{2}{*}{ Interpretation } \\
\cline { 2 - 4 } & Semantic & Communicative & 1 \\
\hline 1 & + & & 1 \\
\hline 2 & + & + & 1 \\
\hline 3 & & + & 2 \\
\hline 4 & + & & 1 \\
\hline 5 & & + & 1 \\
\hline 6 & & & \\
\hline
\end{tabular}

\section{Discussion}

A close look at the renderings above, one can say that subjects gave different translations. Subjects 1,2,5 used semantic translations and succeeded in conveying the written meaning (interpretation 1). As for the fourth subject, he used communicative translation. He succeeded in conveying (interpretation 2) since he depended on listening to the spoken language (phonologically speaking). Regarding subjects 3,6 , they used communicative translation in that they used foregrounding and back grounding (markedness theory). It seems that all groups succeeded in transferring one interpretation and not both. This means that they failed in rendering the ambiguous structure as an ambiguous structure which involves both meanings.

We believe that we can give an ambiguous structure to the SLT structure, but with another meaning which is:

ست، و عشرون جنديا دخلوا المعكر. 


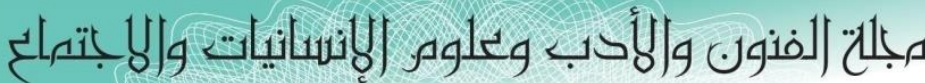

Journal of Arts, Literature, Humanities and Social Sciences

ISSN online: 2414 - 3383

ISSN print: 2616 - 3810

\section{العدد (42) أيلول - سبتمبر 2019}

This means that a lady and twenty soldiers entered the camp.

\section{SLT(3):}

I saw a bat in the garden. (Conway, 2002:10).

Interpretation (1) : the first sense, means : I saw a stick.

Interpretation (2): the second sense means : I saw a bird.

\section{TLTs}

$$
\begin{aligned}
& \text { 1 } \\
& \text { 2. رايت مضربا في الحديقة. } \\
& \text { 3. رايت مضربا في الحديقة. } \\
& \text { 4. رايت خفاثا في الحديقة. } \\
& \text { 5. رايت مضربا في الحديقة. } \\
& \text { 6. رايت مضربا في الحديقة. }
\end{aligned}
$$

Text Analysis (3):

\begin{tabular}{|c|c|c|c|}
\hline \multirow{2}{*}{ Subject } & \multicolumn{2}{|c|}{ Translation } & Interpretation \\
\cline { 2 - 4 } & Semantic & Communicative \\
\hline 1 & + & & 2 \\
\hline 2 & + & & 1 \\
\hline 3 & + & & 1 \\
\hline 4 & + & & 2 \\
\hline 5 & + & & 1 \\
\hline 6 & + & & 1 \\
\hline
\end{tabular}




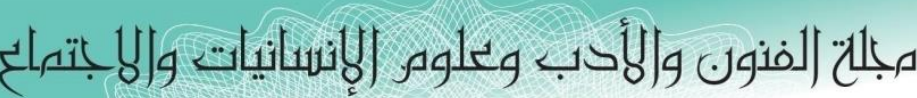

Journal of Arts, Literature, Humanities and Social Sciences

ISSN online: 2414 - 3383

ISSN print: 2616 - 3810

\section{العدد (42) أيلول - لسبتهبر 2019}

\section{Discussion}

In the above example, it is clear that the word "bat" has two meanings. Subjects 1, and 4 focused on the second meaning, whereas subjects 2,3, 5, and 6 confirmed the first meaning. As for renderings, it seems that both groups used semantic translation in that they used the same structure. Hence, it can be said that group one (1 and 4) succeeded in transferring the second sense, whereas the second group $(2,3,5$, and 6) succeeded in conveying the first meaning. However, both failed in transferring the ambiguous structure as an ambiguous structure. This means that this ambiguous structure is untranslatable as ambiguous structure. Here, our suggestion is that a translator in cases of untranslatability should give footnote about.

\section{SLT(4)}

I like my friend more than my colleague.

(Alexander, $2008: 50)$

Interpretation (1) : I like my friend more than I like my colleague.

Interpretation. (2) : I like my friend more than my colleague likes him.

\section{TLTs :}

Text Analysis (4):

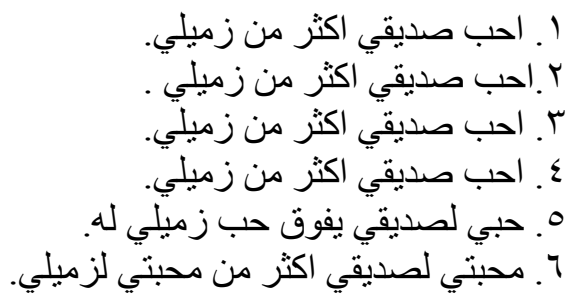

\begin{tabular}{|c|c|c|c|}
\hline \multirow{2}{*}{ Subject } & \multicolumn{2}{|c|}{ Translation } & Interpretation \\
\cline { 2 - 4 } & Semantic & Communicative & $1+2$ \\
\hline 1 & + & & $1+2$ \\
\hline 2 & + & + & $1+2$ \\
\hline 3 & + & + & 2 \\
\hline 4 & & + & 2 \\
\hline 5 & & & 2 \\
\hline 6 & & & \\
\hline
\end{tabular}




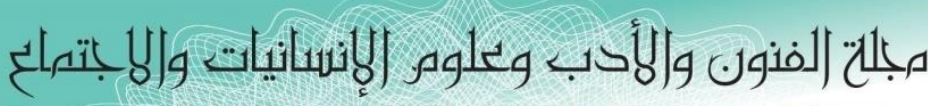

Journal of Arts, Literature, Humanities and Social Sciences

ISSN online: 2414 - 3383

ISSN print: 2616 - 3810

\section{العدد (42) أيلول -سبتمبر 2019}

\section{Discussion:}

In example (4) and its renderings, one can that subjects 1,2,3, and 4 translated the text semantically. Indeed, subjects succeeded in transferring the structure under investigation into Arabic as an ambiguous structure. However, subjects 5 abs 6 translated the SLT communicatively because they used a nominal structure. Both subjects 5 and 6 failed in conveying the ambiguous structure into ambiguous structure; yet, they succeeded in conveying one sense. Subject 5 conveyed interpretation (2). However,

subject 6 succeeded in transferring interpretation (1). Consequently, the best rendering is:

$$
\text { احب صديقي اكثر من زميلي. }
$$

\section{SLT(5)}

Susan and George are married.

(Havarkate,1984: 56)

Interpretation (1) Both Susan and George are married to other people.

Interpretation. (2) Susan married George.

\section{TLTs}

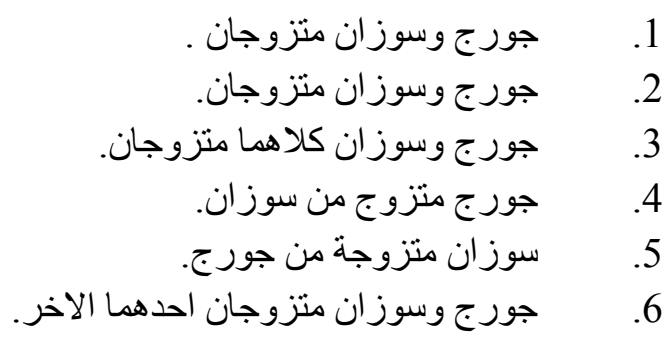




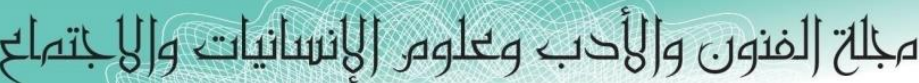

Journal of Arts, Literature, Humanities and Social Sciences

ISSN online: 2414 - 3383

ISSN print: 2616 - 3810

العدد (42) أيلول - سبتهبر 2019

Text Analysis (5):

\begin{tabular}{|c|c|c|c|}
\hline \multirow{2}{*}{ Subject } & \multicolumn{2}{|c|}{ Translation } & Interpretation \\
\cline { 2 - 4 } & Semantic & Communicative & $1+2$ \\
\hline 1 & + & & $1+2$ \\
\hline 2 & + & & $1+2$ \\
\hline 3 & + & + & $1+2$ \\
\hline 4 & + & + & 2 \\
\hline 5 & & & 1 \\
\hline 6 & & & \\
\hline
\end{tabular}

\section{Discussion:}

From the aforementioned translations, it can be said that all subjects used communicative translation in that, they all used nominal structures, whereas the source language text is verbal. Subjects 4,5, and 6 succeeded in their translations since they could transfer one sense of the structure in question; therefore, they failed in transferring the structure under investigation into ambiguous structure in Arabic. Regarding subjects $1,2,3$, succeeded in their renderings since, they could translate the structure under discussion into an ambiguous structure in Arabic.

\section{SLT(6)}

The chicken is ready to eat.

(Havarkate, $1984: 20)$

Interpretation (1): it means that the chicken is ready to eat something.

Interpretation (2) : it means that the chicken is ready to be eaten by someone.

\section{TLTs}

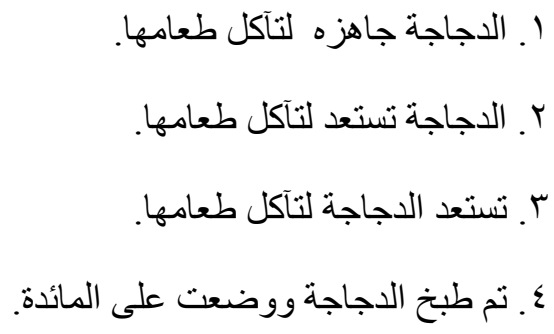


مبلحت لفنون والأدب وعلوه الإنسانيات والبنتماع

Journal of Arts, Literature, Humanities and Social Sciences

ISSN online: 2414 - 3383

ISSN print: 2616 - 3810

العدد (42) أيلول - سبتهبر 2019

Text Analysis (6):

\begin{tabular}{|c|c|c|c|}
\hline \multirow{2}{*}{ Subject } & \multicolumn{2}{|c|}{ Translation } & Interpretation \\
\cline { 2 - 4 } & Semantic & Communicative & 1 \\
\hline 1 & + & & 1 \\
\hline 2 & + & & 1 \\
\hline 3 & + & + & 2 \\
\hline 4 & & + & 2 \\
\hline 5 & + & & $1+2$ \\
\hline 6 & & & \\
\hline
\end{tabular}

\section{Discussion:}

A close inspection of the above mentioned example and it's renderings, it can be said that subjects 1, 2, 3 used semantic translation. They succeeded in conveying the first meaning. As for subjects 4 and 5, they both used communicative translation and succeeded in transferring the second meaning. Regarding subject 6 , he succeeded in conveying the ambiguous structure as an ambiguous structure; therefore, the most successful translation is No. 6.since it is a similar structure like the source language text.

\section{SLT(7):}

The lawyer said, on Sunday, I will have a trial. ( Trosberg,1994 : 60)

Interpretation (1) : it means that on Sunday, the lawyer said he will have a trial.

Interpretation (2): it means that the trial will be on Sunday .

TLTs:

$$
\text { ا. قال المحامي يوم الأحد سأحضر المر افعة. }
$$




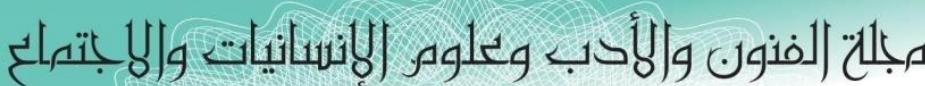

Journal of Arts, Literature, Humanities and Social Sciences

ISSN online: 2414 - 3383

ISSN print: 2616 - 3810

\section{العدد (42) أيلول - سبتهبر 2019}

$$
\begin{aligned}
& \text { r. في يوم الاحد قال المحامي، سأحضر المر افعة . } \\
& \text { r. قال المحامي سأحضر المر افعة في يوم الاحد. } \\
& \text { ع. قال المحامي ستكون المر افعة في يوم الاحد. } \\
& \text { ○. قال المحامي في يوم الاحد سأحضر المر افعة. } \\
& \text { T. قال المحامي ستكون المر افعة يوم الاحد. }
\end{aligned}
$$

Text Analysis (7):

\begin{tabular}{|c|c|c|c|}
\hline \multirow{2}{*}{ Subject } & \multicolumn{2}{|c|}{ Translation } & Interpretation \\
\cline { 2 - 4 } & Semantic & Communicative & \\
\hline 1 & + & + & $1+2$ \\
\hline 2 & & + & \\
\hline 3 & & + & \\
\hline 4 & + & + & $1+2$ \\
\hline 5 & & & \\
\hline 6 & & & \\
\hline
\end{tabular}

\section{Discussion:}

In this example and its renderings, it can be said that subjects, 3, 4, 6 have used communicative translations. They succeeded in transferring the second meaning. As for subjects 1 and 5 , it seems that they used semantic translation. They both succeeded in conveying the structure in question with the same effect to that of the source language. Regarding rendering 2, it seems that the subject has used communicative translation. He succeeded in conveying the first meaning. Regarding, 1 and 5 it seems, that both succeeded in transferring the structure in question to Arabic with the same effect as to that of target language.

\section{$\operatorname{SLT}(8)$}

Look at that poor man with one eye.

(Havarkate,1984 :25).

Interpretation (1) : look at that poor man who has one eye. 


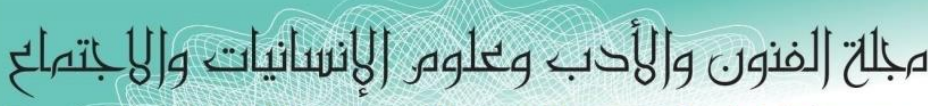

Journal of Arts, Literature, Humanities and Social Sciences

ISSN online: 2414 - 3383

ISSN print: 2616 - 3810

\section{العدد (42) أيلول - سبتمبر 2019}

Interpretation. (2) close one eye and then look at that poor man.

TLTs :

$$
\begin{aligned}
& \text { 1. انظر الى ذلك الرجل الفقبر بعين واحدة. } \\
& \text { r. انظر الى ذلك الرجل الفقير بعين واحدة. } \\
& \text { r. انظر الى ذلك الرجل الفقير بعين واحدة. } \\
& \text { ع. بعين واحدة، انظر الى ذلك الرجل الفقير. } \\
& \text { ○ـ انظر الى ذلك الرجل الفقير ذو العين الواحدة. } \\
& 7 \text { 7. انظر الى ذللك الرجل الفقيربعين واحدة. }
\end{aligned}
$$

Text Analysis (8)

\begin{tabular}{|c|c|c|c|}
\hline \multirow{2}{*}{ Subject } & \multicolumn{2}{|c|}{ Translation } & \multirow{2}{*}{ Interpretation } \\
\cline { 2 - 4 } & Semantic & Communicative & $1+2$ \\
\hline 1 & + & & $1+2$ \\
\hline 2 & + & & $1+2$ \\
\hline 3 & + & & 2 \\
\hline 4 & + & + & 1 \\
\hline 5 & + & & $1+2$ \\
\hline 6 & & & \\
\hline
\end{tabular}

\section{Discussion:}

A look at the example above with its renderings, it can be said that subjects 1,2,3,5, and 6 have used semantic translation in that they kept the same structure of that of the target language. As for subject 4 , he used communicative translation. Concerning the senses of the structure under investigation, subjects 1,2,3, and 6 succeeded in conveying the structure under discussion as an ambiguous structure into Arabic. Regarding subjects 4 and 5, it seems they failed in conveying both senses. No. 4 conveyed the second sense, whereas the fifth subject transferred the first sense. 


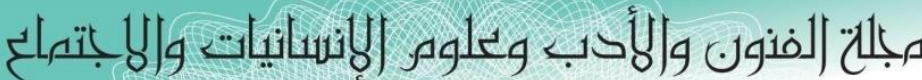

Journal of Arts, Literature, Humanities and Social Sciences

ISSN online: 2414 - 3383

ISSN print: 2616 - 3810

العدد (42) أيلول - سبتمبر 2019

\section{SLT(9)}

John hit the man with a stick. $\quad$ (Trosborg, 1994: 45)

Interpretation (1) : it means that John hit the man who has a stick.

Interpretation (2) : it means that John hit with his stick the man.

\section{TLTs :}

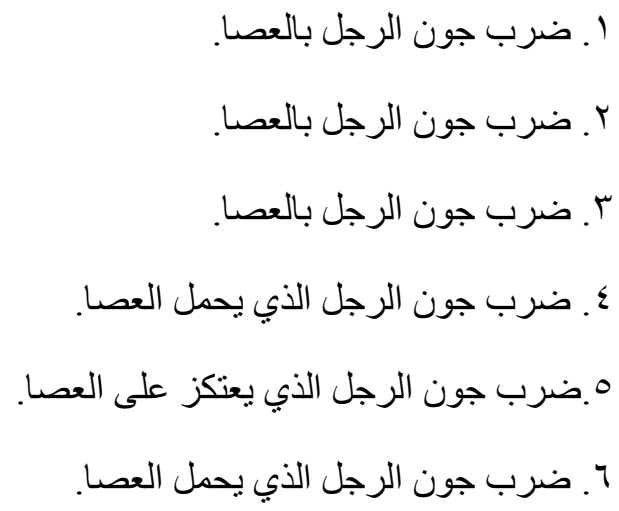

Text Analysis (9):

\begin{tabular}{|c|c|c|c|}
\hline \multirow{2}{*}{ Subject } & \multicolumn{2}{|c|}{ Translation } & Interpretation \\
\cline { 2 - 4 } & Semantic & Communicative & $1+2$ \\
\hline 1 & + & & $1+2$ \\
\hline 2 & + & + & $1+2$ \\
\hline 3 & + & + & 1 \\
\hline 4 & & + & 1 \\
\hline 5 & & & 1 \\
\hline 6 & & & \\
\hline
\end{tabular}




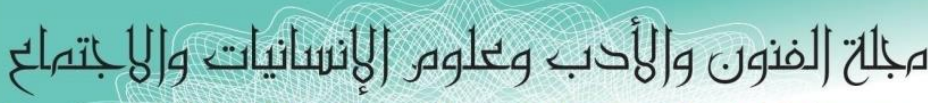

Journal of Arts, Literature, Humanities and Social Sciences

ISSN online: 2414 - 3383

ISSN print: 2616 - 3810

\section{العدد (42) أيلول -سبتمبر 2019}

\section{Discussion:}

A close look at the source language text and its renderings reveals that subjects $1,2,3$ have used semantic translation. They succeeded in translating the ambiguous text under investigation into an ambiguous structure in Arabic. Regarding subjects 4,5 , and 6 , they translated the source language text communicatively in that they added some words. They succeeded in transferring just one sense, which is the first sense. However, they failed to convey the text into Arabic as an ambiguous structure.

\section{SLT(10)}

There is an ice toy in the garden.

(Shane, 2000:7)

Interpretation (1): phonologically, this example in spoken language is ambiguous in that it may be heard by the listener as " a nice toy ". Or:

Interpretation (2): as an ice toy.

\section{TLTs :}

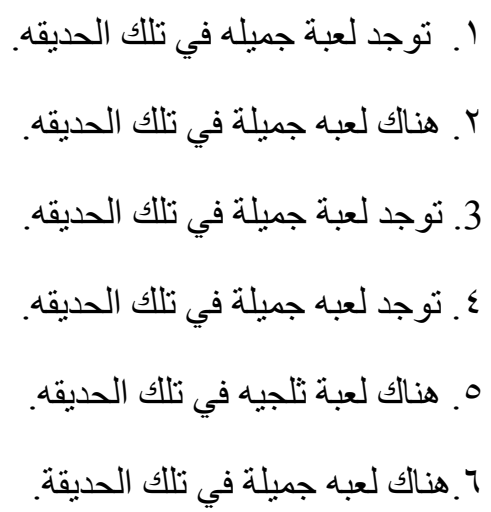




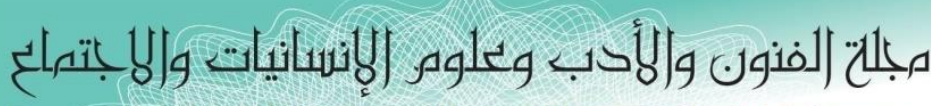

Journal of Arts, Literature, Humanities and Social Sciences

ISSN online: 2414 - 3383

ISSN print: 2616 - 3810

العدد (42) أيلول - سبتمبر 2019

Text Analysis (10):

\begin{tabular}{|c|c|c|c|}
\hline \multirow{2}{*}{ Subject } & \multicolumn{2}{|c|}{ Translation } & \multirow{2}{*}{ Interpretation } \\
\cline { 2 - 4 } & Semantic & Communicative & 1 \\
\hline 1 & + & & 1 \\
\hline 2 & + & & 1 \\
\hline 3 & + & & 1 \\
\hline 4 & + & & 2 \\
\hline 5 & + & & 1 \\
\hline 6 & + & & 1 \\
\hline
\end{tabular}

Discussion:

In this ambiguous structure and its renderings, it seems that subjects 1,2, 3, 4, and 6 have translated it semantically and conveyed one meaning which is that the toy is nice.In regard to subject 5, it seems that he also used semantic translation according to what he heard phonologically. It is suggested that it can be translated into target language as an ambiguous structure as follows:

$$
\text { توجد لعبه جميلة وتلجية في الحديقة. }
$$

This rendering is ambiguous because there may be a nice toy in the garden and at the same time also an ice toy in it or there may be a nice icy toy in the garden.

\section{SLT(11)}

University campus is open to faculty members and all employees only on

Saturdays in summer vacation.

(Allwood, 1985: 56)

Interpretation (1) : it means only faculty members and employees allowed to be in the campus of the university.

Interpretation (2) : it means that faculty members and employees are to be attended only on Saturdays. 


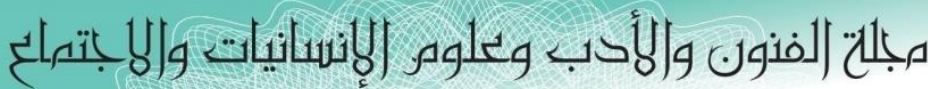

Journal of Arts, Literature, Humanities and Social Sciences

ISSN online: 2414 - 3383

ISSN print: 2616 - 3810

\section{العدد (42) أيلول - لسبتمبر 2019}

TLTs.

$$
\begin{aligned}
& \text { ا. ان الحرم الجامعي مفتوح لاعضاء الهيئة التدريسية و الموظفين فقط يوم السبت في العطلة الصيفية. } \\
& \text { r . ان الحرم الجامعي مفتوح لاعضاء الهيئة التدريسية و الموظفين فقط في ايام السبت في العطلة الصيفية. } \\
& \text { r. ان الحرم الجامعي مفتوح لاعضاء الهيئة التدريسية و الموظفين فقط يوم السبت في العطلة الصيفية. } \\
& \text { ـ. ان الحرم الجامعي مفتوح لاعضاء الهيئة التدريسية و الموظفين فقط يوم السبت في العطلة الصيفية. } \\
& \text { 0. ان الحرم الجامعي مفتوح لاعضاء الهيئة التدريسية والموظفين يوم السبت فقط في العطلة الصيفية. } \\
& \text { 6. ان الحرم الجامعي مفتوح لاعضاء الهيئة التدريسية و الموظفين يوم السبت فقط في العطلة الصيفية. }
\end{aligned}
$$

\section{Text Analysis (11):}

\begin{tabular}{|c|c|c|c|}
\hline \multirow{2}{*}{ Subject } & \multicolumn{2}{|c|}{ Translation } & Interpretation \\
\cline { 2 - 4 } & Semantic & Communicative & $1+2$ \\
\hline 1 & + & & $1+2$ \\
\hline 2 & + & & $1+2$ \\
\hline 3 & + & + & $1+2$ \\
\hline 4 & + & + & 2 \\
\hline 5 & & & 2 \\
\hline 6 & & & \\
\hline
\end{tabular}

\section{Discussion:}

A close inspection of the example under investigation and its renderings, it can be said

that subjects $1,2,3,4$, have translated the source text semantically. They succeeded in rendering the text as an ambiguous structure in Arabic. As for subjects 5 and 6, they translated the text communicatively. They succeeded in conveying only the second meaning which is attending only on Saturdays. 


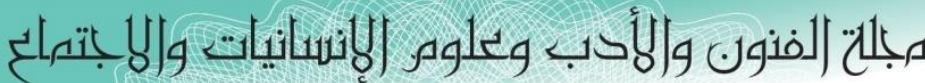

Journal of Arts, Literature, Humanities and Social Sciences

ISSN online: 2414 - 3383

ISSN print: 2616 - 3810

العدد (42) أيلول - لسبتمبر 2019

\section{SLT(12)}

The Italian professor is really very clever. ( Berry et al, 2003: 37)

Interpretation (1): The professor whose nationality is Italian.

Interpretation (2): The professor of Italian language.

TLTs :

$$
\begin{aligned}
& \text { 1. حقا الاستاذ الإيطالي ذكي جدا. } \\
& \text { ץ.اجل الاستاذ الإيطالي في قمة الذكاء. } \\
& \text { r. فعلا الاستاذ الإيطالي ذكي جدا. } \\
& \text { ع. حقا الاستاذ الإيطالي جدا ذكي. } \\
& \text { ๑. حقا استاذ اللغة الإيطالية ذكي جدا. } \\
& \text { 7. اجل استاذ اللغة الإيطالية في قمة الذكاء. }
\end{aligned}
$$

Text Analysis (12):

\begin{tabular}{|c|c|c|c|}
\hline \multirow{2}{*}{ Subject } & \multicolumn{2}{|c|}{ Translation } & \multirow{2}{*}{ Interpretation } \\
\cline { 2 - 4 } & Semantic & Communicative & 1 \\
\hline 1 & + & & 1 \\
\hline 2 & + & & 1 \\
\hline 3 & + & & 1 \\
\hline 4 & + & + & 2 \\
\hline 5 & & + & 2 \\
\hline 6 & & & \\
\hline
\end{tabular}




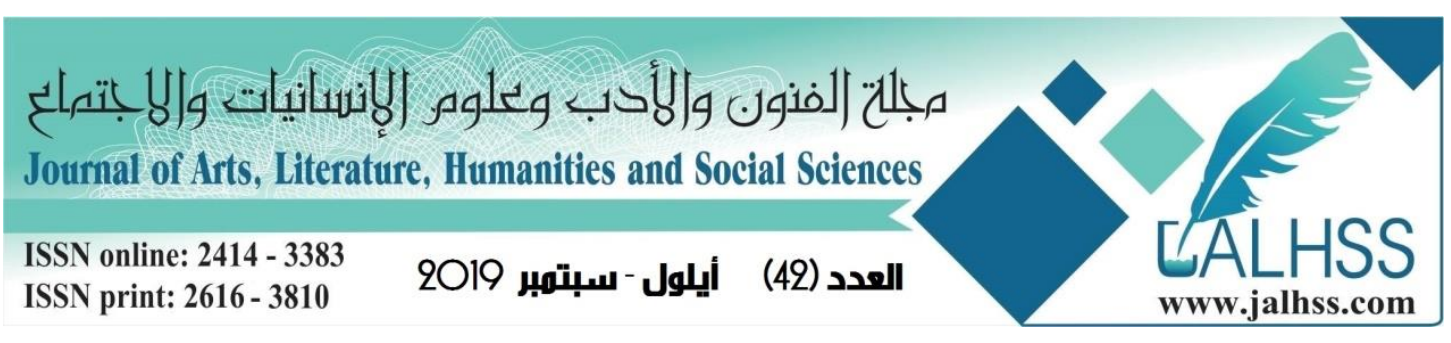

\section{Discussion:}

Subjects 1, 2, 3, and 4 have translated the structure under discussion semantically. They succeeded in conveying only in the first sense. As for the translators 5 and 6 , it seems that they used communicative translation. Regarding the transference of the meaning, they conveyed only the second meaning. This type of ambiguity can be solved by resorting to the context of situation as well as linguistic context (co-text). Here, it is advisable to use communicative translation or even adaptation in that adding . Some elements or deleting some other elements. Consequently, the following rendering is proposed.

\section{Conclusions}

1. Ambiguity in any language means that a linguistic unit has more than one meaning or more than one interpretation. Sometimes it has a bundle of meanings. This multiplicity of meaning results in block in communication. The listener or the addressee is sometimes confused in receiving the intention of the speaker or writer. However, once the context of the situation and/ or the linguistic context (co-text) are clear or there, the problem can be solved easily.

2. The title of the paper is "The Translation of the Ambiguous Structures from English into Arabic. The word structure does not mean in our study that the paper is only about the "Syntactic Ambiguity" since every linguistic unit has got a structure. Hence, come the structural semantics, structural Pragmatics, structural grammar, and structural phonology. As it is well known languages have got structures. The units of languages are phonemes which consist of allophones, morphemes which consist of free morphemes, bound morphemes, words which consist of bases, suffixes, prefixes, infixes, phrases which consist of words and compound words, sentences, which consist of words and phrases and so on. Very briefly language is a systematic structure.

3. Structure alone does lead to know the meaning of the linguistic unit, simply, because the meaning is the outcome of the structure and elements of the structure. Hence, semantics emerges which is the scientific study of meaning. Meaning is something abstract and to know it or get it depends upon intuition and the intention of the speaker, writer or addressor. Hence, our notion of structure and ambiguous structure, since structure without semantic and psychological intuition cannot result in understanding the ambiguous structure. 


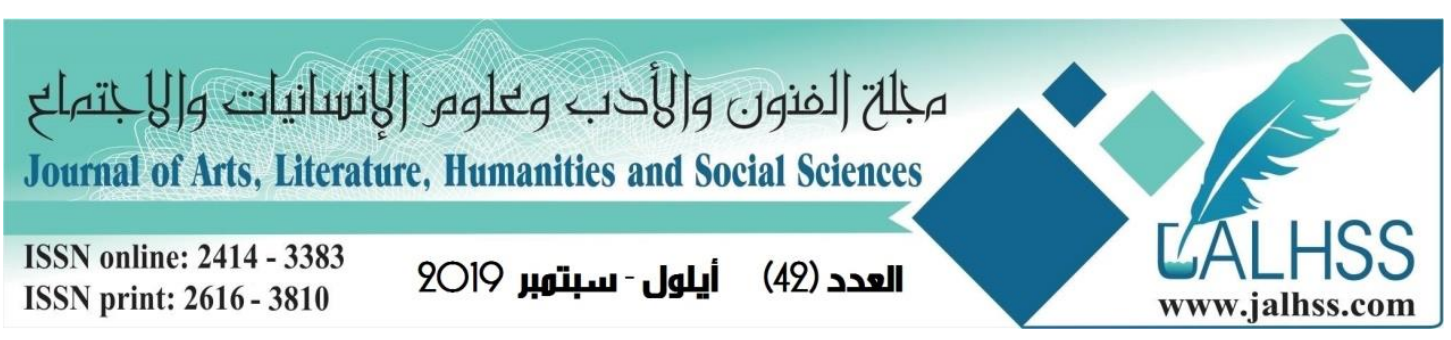

4. In regard to translation, it seems that most subjects succeeded in transferring one meaning of the ambiguous structures and not both or all meanings of the texts under investigation, i.e., they ran into the problem of untranslatability. Hence, some of them resort to communicative translation or even adaptation in or to transfer both means of the texts under translation and they did succeed.

5. The reasons behind not giving sometimes effective renderings are due to the differences between the languages in question, since English and Arabic are genetically different languages belonging to different families.

6. There is no formal correspondence between source language texts and target language texts in question. However, having encyclopedic knowledge of languages under investigation result in giving appropriate renderings and effective ones similar to that of the source language texts. This means that ambiguous structures in the source language can be translated as ambiguous structures in the target language if and only if the translator is aware of semantics, pragmatics, stylistics, syntactics, phonology, morphology, phraseology as well as having psychological intuition of the intention of the speaker, writer or the addressor. Hence, comes intentionality which involves mental states of both the writer and the reader.

\section{REFERENCES}

1. Al-Sulaimaan, M. M. D. (2016) : Translation: Theory and Practice, Erbil: Haval Printing Press.

2. Al-Sulaimaan, M.M.D. (2016) : Semantics and Pragmatics, Erbil: Haval Printing Press.

3. As-Saafi, A. B. (2008) : Translation Theories : Strategies and Basic Theoretical Issues, Petra: Petra University Press.

4. Baker, G. (2006) : Translation and Conflict: A narrative Account, London: Routledge.

5. Bassnett, S. (1991) : Translation Studies, London: Routledge.

6. Bassnett, S. and Lefevere,A. (1990): Translation, History and Culture, London: Pinter Press.

7. Bates, E. (2007) : Language and Context: The Acquisition of Pragmatics, New York Academic Press Inc.

8. Berry, D.M. ,E. Kamsties, and M.M. (2003): "From Contract Draft to Software Specification: Linguistics Sources of Ambiguity" . In : Journal of Systems Softwares, Vol.28, No.2, pp.1-70.

9. Bhabha, H. (1994) : The Location of Culture, London : Routledge. 


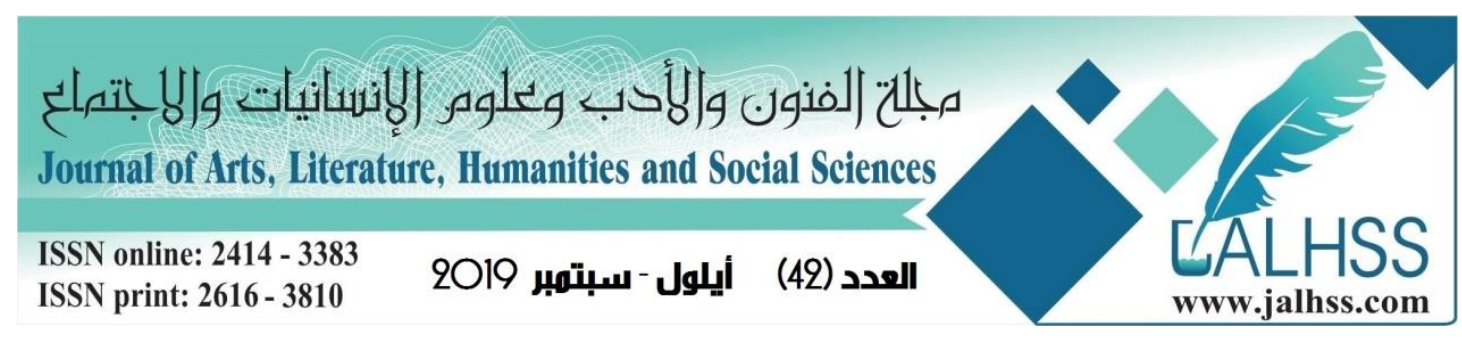

10. Catford, J.C. (1965): A Linguistic Theory of Translation, London: Oxford University Press.

11. Conway, P. (2002): "Syntactic Ambiguity". In : Law and Justice Foundation of NSW,pp.1-45.

12. Gunn,R.W. (1999) : Ambiguity: Strategic Finance, Accompli: Accopli Group Ltd.

13. Hurfard, J.R. B. Hearsley, and M.B.Smith, (2007) : Semantics: A Course Book, Cambridge: Cambridge University Press, 2nd., Edition.

14. Jakobson, R. (1967) : " On Linguistic Aspects of Translation “. In :

15. R.A.Brower (ed.), On Translation, Cambridge: Cambridge University Press.

16. Keenan, E.L. (1975): Formal Semantics of Natural Language,

17. Cambridge: Cambridge University Press.

18. Larson, M. L.(1984): Meaning Based Translation: A Guide to Cross Language Equivalence, London: American University Press.

19. Neubert, A. and Shreve, G. (1992): Translation as Text, Kent State: Kent University Press.

20. Newmark, P. (1988a): Approaches to Translation, Oxford and New York: Pergamon.

21. Newmark, P. (1988b) : A Textbook of Translation, London: Prentice Hall.

22. Newmark, P. (1991): About Translation, Philadelphia: Multilingual Matters Ltd.

23. Newman, A. (2009): Mapping Translation Equivalence, Leuven: Acco.

24. Nida, E. (1982): Translating Meaning, San Dimas, California : English

25. Language Institute Press.

26. Monz, C. (1998) : “ Dynamic Semantics and Ambiguity “. In :Prade, H.(ed.) Proceedings of the 13th., European Conference On Artificial Intelligence (ECAI 98), pp.212-222.

27. Muhonen, K. and Purtonen, T. (2012) : "Detecting Semantic Ambiguity:

28. Alternative Readings in Treebanks". In: Linguistic Issues in Language and Technology, Vol.6, No. 17, pp.1-11.

29. Poesio, M. and Artstein, R. (2005) :"Annotating (Analhoric) Ambiguity". in: Corpus linguistics, Birmingham: Birmingham University Press,pp.1-20.

30. Savory, T. (1968): The Art of Translation, Boston: The Writer, Inc.

31. Shane, S. (2000) : "Ambiguity and Misunderstanding in the Law". In:Words and Phrases, Harvard : Harvard University Press, pp1 20.

32. Trosborg, A. (1994) : Interlanguage Pragmatics, Requests, Complaints and Apologies: Mouton de Gruyter. 